\title{
ERG Gene
}

National Cancer Institute

\section{Source}

National Cancer Institute. ERG Gene. NCI Thesaurus. Code C18139.

This gene plays a regulatory role in transcription, cellular maintenance and hematopoiesis. 